\title{
THE INFLUENCE OF A SPECIFIC TOURIST AND SIGHTSEEING PROGRAM ON REGION RELATED KNOWLEDGE
} School and educational tourism

\author{
KRZYSZTOF H. WOJCIECHOWSKI, MARCIN BOCHENEK, \\ PRZEMYSŁAW KĘDRA, BEATA RAFALSKA \\ The Josef Pilsudski University of Physical Education in Warsaw, \\ Faculty of Physical Education and Sport in Biała Podlaska, Department of Tourism \\ Mailing address: Krzysztof Wojciechowski, Faculty of Physical Education and Sport, \\ 2 Akademicka Street, 21-500 Biała Podlaska, tel.: +48 83 3428700, fax: +48 83 3428800, \\ e-mail: krzysztof.wojciechowski@awf-bp.edu.pl
}

\begin{abstract}
Introduction. Participation in properly organized tourism events based the tourist potential of the region, becomes a creative experience, generating creative attitude, satisfying a number of needs and aspirations [2]. Tourism has the potential to contribute to increased effectiveness of school education. It can affect attitudes and develop appropriate habits in terms of physical activity. However, it must be accompanied by appropriate offer of activities, which is likely to generate a desirable behaviour. The purpose of this paper is to determine the influence of a specific tourism program on region related knowledge on the part of male and female students. Material and methods. The research conducted by way of pedagogical experiment utilizing the technique of parallel groups forms merely a small part of the entire research program carried out at the Department of Tourism of the Faculty of Physical Education and Sport in Biała Podlaska. The research was carried out in two stages - 2002-2003 and 2009-2010 and involved a total group of 272 subjects. Results and conclusions. Based on the obtained results it can be concluded that the proposed specific tourism program does advance the level of region related knowledge, and its impact is greater than the implementation of tasks resulting from the educational process of the contemporary school.
\end{abstract}

Key words: school tourism, education, specific program

\section{Introduction}

Tourism activity in its various forms provides ample opportunity to work on the development of observational capacities of children and young people as well as teaches how to notice new aspects of well-known phenomena and objects. Tourist peregrinations around a region where we usually live provide us with an abundant opportunity to gain cognitive experience. They facilitate direct contact with historical and natural objects, which can be a source of knowledge and aesthetic, patriotic as well as moral experiences [4].

Owing to its natural and other values the region of Southern Podlasie is a favourable place for the development of tourism. The lack of cumbersome industry and the typically agricultural nature, additionally make the environment very attractive. The landscape and its accessibility are good allies in the organization of tourism, especially its active forms, while the region is characterized by a wide range of roads, tracks and trails. Tourism in the southern part of Podlasie offers a range of opportunities to explore the landscapes, the people and the various historical monuments and cultural products of culture.

The aim of the research presented in this paper is to determine the effect of a specific tourism programme on the level of region related knowledge on the part of male and female students.

\section{Material and methods}

The research utilized the method of pedagogical experiment with the technique of parallel groups as well as initial and final measurement. 272 male and female primary school students in the southern part of Podlasie, aged 11-12, participated in the research (Tab. 1).

Table 1. Research participants

\begin{tabular}{|l|c|c|c|}
\hline \multicolumn{1}{|c|}{ Subjects } & N & $\%$ & Years \\
\hline $\begin{array}{l}\text { Children and youths - pedagogical experiment } \\
\text { (experimental and control group) - (research I) }\end{array}$ & 138 & 50.74 & $\begin{array}{l}2002 \\
2003\end{array}$ \\
\hline $\begin{array}{l}\text { Children and youths - pedagogical experiment } \\
\text { (experimental and control group) - (research II) }\end{array}$ & 134 & 49.26 & $\begin{array}{l}2009 \\
2010\end{array}$ \\
\hline Total & 272 & 100 & \\
\hline
\end{tabular}

Source: Own research

The research was carried out in two stages from 2002 to 2010. Stage I took place in the spring (March) of 2002 and in the autumn (October) of 2003, while Stage II, which was a repeat of the previous research: took place from the autumn (October) of 2009 to the winter (December) of 2010. Based on the parallel- 
groups technique, also referred as the two groups plan with initial and final measurement, the researchers attempted to identify and assess the suitability of a specific tourism program in the education of students. In order to evaluate the knowledge about the region of Southern Podlasie the researchers used an especially adapted "Filed guessing game".

In March 2002 - Stage I and in October 2009 - Stage II, after the completion of the initial testing, a specific program "Tourism in my Region - Tourism for the Children" was implemented at schools. The program was pursued only by the experimental groups. The control class participated in tourism on the basis of existing educational programs offered by the school.

The specific tourism program was based on the five areas of education: adventure and tourism education, physical education, regional education - cultural heritage in the region, environmental education and socio-moral education. The program took into account the basics of teaching and educational activities conducted in the field - as indicated by K. Denek - it involved "education out of the classroom" [5] in all seasons. The tasks performed by the participants required proper preparation, both before the trips, as well as during their course. The specific program was approved by the school authorities and the boards of teachers of individual schools. The final survey of the experimental and the control group was carried out in October 2003 - Stage I and in December 2010 - Stage II, using the same research tools.

\section{Results}

Based on the conducted research, at an interval of 6 years, a comparative analysis was performed of the experimental group - i.e. the students participating in the specific tourism program and the control group, pursuing the usual course of education offered by the school.

The initial survey results indicated similar levels of knowledge about the region on the part of the subjects surveyed in Stage I - 2002-2003. In the same survey conducted 6 years later, the experimental group outperformed the control group before the introduction of the variable (Tab. 2).

Table 2. Knowledge about the region of residence amongst participant of the experimental and the control group - initial survey

\begin{tabular}{|l|c|c|c|c|c|c|c|c|}
\hline \multirow{3}{*}{ Answers } & \multicolumn{3}{|c|}{ Years 2003-2004 } & \multicolumn{3}{c|}{ Years 2009-2010 } \\
\cline { 2 - 9 } & $\begin{array}{c}\text { Experimental } \\
\text { group }\end{array}$ & $\begin{array}{c}\text { Control } \\
\text { group }\end{array}$ & $\begin{array}{c}\text { Experimental } \\
\text { group }\end{array}$ & $\begin{array}{c}\text { Control } \\
\text { group }\end{array}$ \\
\cline { 2 - 9 } & $\mathbf{N}$ & $\%$ & $\mathbf{N}$ & $\%$ & N & $\%$ & N & $\%$ \\
\hline Correct & 441 & 52.5 & 440 & 54.7 & 509 & 56.0 & 435 & 48.0 \\
\hline Incorrect & 399 & 47.5 & 364 & 45.3 & 403 & 44.0 & 477 & 52.0 \\
\hline Total & 840 & 100.0 & 804 & 100.0 & 912 & 100.0 & 912 & 100.0 \\
\hline Chi-square test & \multicolumn{4}{|c|}{$\mathrm{x}^{2}=0.82 / \mathrm{p}>0.05$} & \multicolumn{3}{c|}{$\mathrm{x}^{2}=12.02 / \mathrm{p}<0.001 / \mathrm{C}_{\text {KоR }}=0.08$} \\
\hline
\end{tabular}

Source: Own research

In the final survey, conducted after the implementation of the specific program "Tourism in my region ..." we observed similar changes. In the both surveyed groups, both in the Stage I and Stage II of the educational experiment, there were more students providing correct answers to questions regarding the southern part of Podlasie. In the experimental groups, this increase was much greater. The value of $x^{2}$ test shows that the difference in the knowledge between the groups surveyed in 2002-2003 and the repeated tests in 2009-2010 is statistically significant at the highest level. However the strength of the relationship between the variables is small (Tab. 3).

Table 3. Knowledge about the region of residence amongst participant of the experimental and the control group - final survey

\begin{tabular}{|l|c|c|c|c|c|c|c|c|}
\hline \multirow{3}{*}{ Answers } & \multicolumn{3}{|c|}{ Years 2003-2004 } & \multicolumn{3}{c|}{ Years 2009-2010 } \\
\cline { 2 - 9 } & $\begin{array}{c}\text { Experimental } \\
\text { group }\end{array}$ & $\begin{array}{c}\text { Control } \\
\text { group }\end{array}$ & $\begin{array}{c}\text { Experimental } \\
\text { group }\end{array}$ & $\begin{array}{c}\text { Control } \\
\text { group }\end{array}$ \\
\cline { 2 - 9 } & $\mathbf{N}$ & $\%$ & $\mathbf{N}$ & $\%$ & N & $\%$ & N & $\%$ \\
\hline Correct & 622 & 74.0 & 511 & 63.5 & 704 & 77.0 & 513 & 56.0 \\
\hline Incorrect & 218 & 26.0 & 293 & 36.5 & 208 & 23.0 & 399 & 44.0 \\
\hline Total & 840 & 100.0 & 804 & 100.0 & 912 & 100.0 & 912 & 100.0 \\
\hline Chi-square test & \multicolumn{4}{|c|}{$\mathrm{x}^{2}=21.10 / \mathrm{p}<0.001 / \mathrm{C}_{\mathrm{KoR}}=0.11$} & \multicolumn{3}{c|}{$\mathrm{x}^{2}=90.08 / \mathrm{p}<0.001 / \mathrm{C}_{\mathrm{KoR}}=0.22$} \\
\hline
\end{tabular}

Source: Own research

In order to fully present the effects of the concerned study program on the knowledge of its participants, an analysis of the results obtained in the experimental group at the beginning and at the end of the survey was carried out. In 2002-2003, at the beginning of the experiment, the percentage of people providing correct answers as compared to those providing wrong answers was only $5.0 \%$, in 2009-2010 it was $12.0 \%$. These numbers changed significantly in the final survey, and the difference in Stage I of the survey was $48.0 \%$, and $54.0 \%$ in $2009-2010$. In the both presented cases, the differences were statistically significant at the highest level of $\mathrm{p}<0.001$ (Tab. 4).

Table 4. Knowledge about the region of residence amongst participant of the experimental group in the initial and the final survey

\begin{tabular}{|l|c|c|c|c|c|c|c|c|}
\hline \multirow{3}{*}{ Answers } & \multicolumn{3}{|c|}{ Years 2003-2004 } & \multicolumn{3}{c|}{ Years 2009-2010 } \\
\cline { 2 - 9 } & $\begin{array}{c}\text { Initial } \\
\text { survey }\end{array}$ & $\begin{array}{c}\text { Final } \\
\text { survey }\end{array}$ & \multicolumn{2}{c|}{$\begin{array}{c}\text { Initial } \\
\text { survey }\end{array}$} & \multicolumn{2}{c|}{$\begin{array}{c}\text { Final } \\
\text { survey }\end{array}$} \\
\cline { 2 - 9 } & N & $\%$ & N & $\%$ & N & $\%$ & N & $\%$ \\
\hline Correct & 441 & 52.5 & 622 & 74.0 & 509 & 56.0 & 704 & 77.0 \\
\hline Incorrect & 399 & 47.5 & 218 & 26.0 & 403 & 44.0 & 208 & 23.0 \\
\hline Total & 840 & 100.0 & 840 & 100.0 & 912 & 100.0 & 912 & 100.0 \\
\hline Chi-square test & \multicolumn{4}{|c|}{$\mathrm{x}^{2}=83.92 / \mathrm{p}<0.001 / \mathrm{C}_{\mathrm{KOR}}=0.22$} & \multicolumn{3}{c|}{$\mathrm{x}^{2}=93.58 / \mathrm{p}<0.001 / \mathrm{C}_{\mathrm{KOR}}=0.22$} \\
\hline
\end{tabular}

Source: Own research

A similar analysis of the knowledge results at the beginning and end of the research was performed in the control group, which pursued the standard tourism program offered by the school. The percentage of people in 2002-2003, who provided correct answers as compared to those providing wrong answers was $9.4 \%$ higher. In stage II - of the research carried out in 20092010, there was a situation in which more students (i.e. 4.0\%), in the test on the southern part of Podlasie, gave incorrect answers. Upon completion of the educational process implemented by the school, and the survey repeated at the end of the studies, an increase in the level of knowledge was reported, in which the results of the non-parametric chi-square test were respectively 12.97 in 2002-2003 and 13.36 in 2009-2010. The differences in both cases were statistically significant at the highest level of significance, but the low correlation coefficient indicates a weak relationship between the variables (Tab. 5). 
Table 5. Knowledge about the region of residence amongst participant of the control group in the initial and the final survey

\begin{tabular}{|l|c|c|c|c|c|c|c|c|}
\hline \multirow{3}{*}{ Answers } & \multicolumn{3}{|c|}{ Years 2003-2004 } & \multicolumn{4}{c|}{ Years 2009-2010 } \\
\cline { 2 - 9 } & $\begin{array}{c}\text { Initial } \\
\text { survey }\end{array}$ & $\begin{array}{c}\text { Final } \\
\text { survey }\end{array}$ & \multicolumn{2}{c|}{$\begin{array}{c}\text { Initial } \\
\text { survey }\end{array}$} & $\begin{array}{c}\text { Final } \\
\text { survey }\end{array}$ \\
\cline { 2 - 9 } & $\mathbf{N}$ & $\%$ & $\mathbf{N}$ & $\%$ & $\mathbf{N}$ & $\%$ & $\mathbf{N}$ & $\%$ \\
\hline Correct & 440 & 54.7 & 511 & 63.5 & 435 & 48 & 513 & 56 \\
\hline Incorrect & 364 & 45.3 & 293 & 36.5 & 477 & 52 & 399 & 44 \\
\hline Total & 804 & 100.0 & 804 & 100.0 & 912 & 100.0 & 912 & 100.0 \\
\hline Chi-square test & \multicolumn{4}{|c|}{$\mathrm{x}^{2}=12.97 / \mathrm{p}<0.001 / \mathrm{C}_{\text {KoR }}=0.09$} & \multicolumn{3}{c|}{$\mathrm{x}^{2}=13.36 / \mathrm{p}<0.001 / \mathrm{C}_{\mathrm{KOR}}=0.09$} \\
\hline
\end{tabular}

Source: Own research

\section{Discussion}

The contemporary didactics is seeking program and organizational solutions that will stand a chance to exclude encyclopaedism and verbalism from the process of education. Teaching and educational activities in conjunction with tourism and sightseeing, in cognitive terms facilitate the exploring of new situations, objects, events, people, environments, landscapes, as well as the products of civilization. They are an excellent form in the learning process [5, 9]. The possibility of direct contact with the reality, which is of conscious and purposeful nature, reinforced by interests, and aspirations of students is multidimensional. Properly conducted classes are appropriate and useful forms of intellectual activity, emotional as well as social [6]

Activities "outside the classroom", as emphasised by K. Denek, have not been subject of an extensive interest in education, nevertheless they aspire to become major components of teaching and educational work [5].

It is therefore necessary to seek solutions that will be able to provide an alternative and will become widely known, and to make that happen one should seek appropriate solutions in terms of teaching programs. One of the first attempts undertaken in 2002-2003, revised and gradually introduced in selected schools of the southern part of the Podlasie region [1], then modified in 2009-2010, taking into account the changes that have occurred in education and tourism was the specific program "Active tourism in my region" - aimed at children and young people. Based on the results of research carried out for this program in two stages and 6 years apart in two parallel groups - an experimental group and a control group - one can say that the initial level of knowledge about the region of Southern Podlasie was very similar in all the analysed cases. Upon completion of the final survey, it was found that the experimental group in the two stages had much greater levels of tourist and sightseeing knowledge than the control group. Analysing the level of knowledge in the initial and final survey, it was found that the increase in knowledge had occurred in all groups. However, there was a higher level of knowledge in the experimental group, which pursued the specific tourism program, which demonstrates the positive effects of the tasks included in the project "Active tourism in my region ...".

W. Pańczyk is an author of research projects on various proposals of "out of school education" pursued based on pedagogical experiments in the form of two parallel groups, described in the literature $[7,8]$. The assumptions of the research conducted by the author include, among others, tourism and recreational activities falling within physical education at various levels of schooling. The author has presented the impact of recreation and tourism activities in the field on healthy lifestyle. He also described the biological, health and educational effects. On the other hand, the research presented in this paper takes into account the educational effects. Tourism is an integral combination of health as well as civic, moral and ecological education, and refers to physical and mental as well as polytechnic education. It should be considered in a number of aspects. Properly pursued education leads to development of interests, shapes problem oriented, alternative and global thinking as well as creates the possibility of verification of knowledge.

The "Active tourism in my region ..." program is not the only proposition. Southern Podlasie is a region that promotes relevant and appropriate tourist behaviour. Issues of regional education are systematically introduced to kindergartens and schools. Tourist attractions of this part of Podlasie are used in the education of people of various age groups. They aim to create a sense of regional identity as well as protection of cultural and natural heritage. These problems seem to be very important, especially now in the age of global information [1, 3].

\section{Conclusions}

The presented results of research carried out in 2002-2003 and 2009-2010 show that properly programmed courses in tourism can be a source of knowledge about the region, as they provide a great opportunity to confront the knowledge and theories learned at school with the reality. Information learnt this way remains in the memory of the participants, and at the same time enhances and enriches the educational process.

Tourism is an attractive form of implementation of teaching and education tasks at contemporary schools. The suggested activities of active tourism mainly carried out in the immediate area contribute significantly to the acquisition and memorization knowledge.

\section{Literature}

1. Bochenek, M. (2008). Tourism in the education of children and youths. Biała Podlaska: AWF. [in Polish]

2. Bochenek, M. (2009). Tourism and region related knowledge of male and female students in Southern Podlasie. Annales UMCS, Sectio B, Vol. LXIV 2. [in Polish]

3. Boczukowa, B. (2009). The use of tourist attractions in the process of regional education in Southern Podlasie. Annales UMCS, Sectio B, Vol. LXIV 2. [in Polish]

4. Denek, K. (2000). In the circle of education, sightseeing and tourism at school. Poznań: Eruditius. [in Polish]

5. Denek, K. (2002). Out of school. Poznań: Wyd. Eruditius. [in Polish]

6. Denek, K. (2011). Education out of classroom and out of school. Poznań: Wyd. WSPiA. [in Polish]

7. Pańczyk, W. (1996). The green recipe. Physical activity as an aid in the development and health of the young generation. Zamość-Warsaw: Urząd Kultury Fizycznej i Turystyki. [in Polish]

8. Pańczyk, W. (2012). Physical education for health. Rzeszów: Uniwersytet Rzeszowski. [in Polish]

9. Turos, L. (1996). Tourism and education. Warsaw: Oficyna Ipsylon. [in Polish]

Submitted: June 8, 2012

Accepted: August 27, 2012 